\title{
KONSEPSI HARTA BERSAMA DARI PERSPEKTIF HUKUM ISLAM, KITAB UNDANG- UNDANG HUKUM PERDATA DAN HUKUM ADAT
}

\author{
Besse Sugiswati \\ Fakultas Hukum Universitas Wijaya Kusuma Surabaya \\ e-mail:kietaw53@yahoo.com
}

\begin{abstract}
ABSTRAK
Perkawinan sebagai konsep tentang persatuan antara laki-laki dan perempuan, sehingga menciptakan harta yang berhubungan dengan perkawinan tersebut. Dalam perkawinan terdapat dua harta yaitu harta bawaan dan harta bersama. Harta bersama merupakan harta benda yang didapat selama perkawinan berlangsung. Ada tiga konsep yang mengulas mengenai harta bersama dari perspektif Hukum Islam, Kitab Undang-Undang Hukum Perdata, dan Hukum Adat. Ketika terjadi perceraian Kompilasi Hukum Islam dan Kitab Undang-Undang Hukum Perdata mengatur bahwa harta bersama akan dibagi dua setengah untuk suami dan setengah untuk istri, sedangkan menurut Hukum Adat pembagian harta bersama diatur secara berbeda dari satu wilayah dengan wilayah lainnya.
\end{abstract}

Kata Kunci: harta bersama, Kompilasi Hukum Islam, KUHPerdata, Hukum Adat.

\begin{abstract}
Marriage which known as the concept of unity between a man and a woman, and therefore creates a property that associated with the marriage. Along the marriage, there are known two types of property, private property and property in marriage. Property in marriage is property that is generated during the marriage. There are three concepts to review property in marriage rules, based on Islamic law, civil law, and customary law. When a marriage ended with divorce, the property in marriage shall be devided. Based on Indonesian Islamic Law and Indonesia civil law, the property in marriage shall be devided half and half for the husband and wife, but according to the community law, the property in marriage shall be devided differently from Indonesian Islamic Law and Indonesian Civil Law, the distribution of the property in marriage according to community law is set differently from one region to another region.
\end{abstract}

Keywords: property in marriage, Compilation of Islamic Law, Civil Law, Customary Law.

\section{PENDAHULUAN}

Perkawinan adalah sesuatu yang sakral dan setiap pasangan suami istri senantiasa mendambakan terciptanya rumah tangga yang sakinah, mawaddah dan warahmah atau dalam istilah Jawa sering disebut adem ayem tentrem. Tatkala kondisi rumah tangga dalam keadaan rukun, umumnya harta kekayaan bersama itu berperan sebagai pelengkap kebahagiaan. Namun, apabila rumah tangga mengalami kondisi yang tidak lagi stabil, maka kemungkinan timbulnya perselisihan dan pertengkaran cukup besar. Acapkali bila perselisihan dimaksud tidak dapat diatasi (out of control), peluang kondisi rumah tangga mencapai puncak perselisihan yang mengarah pada kondisi bubarnya perkawinan semakin besar pula. Apabila perceraian terjadi, sudah dapat dipastikan akan menimbulkan akibat-akibat terhadap orang-orang yang berkaitan dalam satu rumah tangga, dimana dalam hal ini akibat hukumnya yang akan dititikberatkan. Akibat hukum dari perceraian ini tentunya menyangkut pula terhadap anak dan harta kekayaan selama dalam perkawinan.

Memang secara kultural, dalam pembicaraan seputar masalah harta gono-gini terkesan masih tabu di masyarakat. Masyarakat umumnya masih 
memandang sebelah mata mengenai masalah ini. Hal ini dikarenakan permasalahan budaya masyarakat yang masih menganggap Perkawinan itu suci, sakral, bersifat agung dan abadi. Artinya setiap pasangan yang menikah harus menjaga kesuciannya, dari proses perkawinan hingga menata rumah tangganya, karena sakral itulah, membicarakan masalah harta sebelum dan saat perkawinan adalah tabu adanya (Happy Susanto, 2008:1).

Namun pada kenyataannya, pasangan suami istri baru mempersoalkan pembagian harta gono-gini ini setelah adanya putusan perceraian dari pengadilan dan biasanya dalam proses pengadilannya pun sering terjadi keributan tentang pembagian harta gono-gini sehingga kondisi tersebut semakin memperumit proses perceraian tersebut. Hal ini dikarenakan, mereka (calon pasangan suami istri) tidak terfikirkan sama sekali permasalahan harta gono-gini ini. Padahal perceraian bisa saja terjadi, dan permasalahan yang sering muncul dari perceraian ini adalah permasalahan harta gono-gini (Happy Susanto, 2008:1). Penjelasan singkat tersebut akan melahirkan suatu pertanyaan mengenai aturan hukum yang akan ditetapkan oleh lembaga peradilan bila para pihak datang dan ingin menyelesaikan persengketaan tersebut. Gono-gini merupakan istilah hukum yang sudah populer di masyarakat. Dalam Kamus Besar Bahasa Indonesia istilah yang digunakan adalah gana-gini, yang secara hukum artinya harta yang berhasil dikumpulkan selama berumah tangga sehingga menjadi hak berdua suami dan istri (Departemen Pendidikan dan Kebudayaan/ Pusat Bahasa, 2001:330). Konsep dan istilah gonogini sebenarnya diambil dari tradisi jawa. Pengertian awal dari gono-gini adalah berarti anak yang hanya dua bersaudara, laki-laki dan perempuan (dari satu Ayah dan satu Ibu). Pengertian tersebut kemudian dikembangkan sebagai konsep tentang persatuan antara laki-laki dan perempuan dalam ikatan perkawinan. Oleh karena itu harta yang memang berhubungan dengan perkawinan tersebut kemudian disebut dengan harta gono-gini (Happy Susanto, 2008:3).

Secara legal-formal dalam peraturan perundangan di Tanah Air, baik dalam Undang-Undang Nomor 1 Tahun 1974 tentang Perkawinan, Kitab UndangUndang Hukum Perdata (KUHPerdata), maupun dalam Kompilasi Hukum Islam, istilah gono-gini disebutkan menggunakan istilah Harta Bersama.

Dari penjelasan tersebut maka rumusan masalahnya Bagaimanakah Konsepsi Harta Bersama dari Undang-
Undang Nomor 1 Tahun 1974 tentang Perkawinan, Hukum Islam, Kitab Undang-undang Hukum Perdata dan Hukum Adat.

\section{PEMBAHASAN}

\section{Konsepsi Berdasarkan Undang-Undang Nomor 1 Tahun 1974 tentang Perkawinan}

Sebagai dasar utama perkawinan di Indonesia, Undang-Undang Nomor 1 Tahun 1974 tentang Perkawinan telah memuat beberapa pasal tentang harta bersama, tepatnya dalam Bab VII Pasal 35 sampai dengan Pasal 37.

Pada Pasal 35 Undang-Undang Perkawinan menyatakan bahwa Harta benda yang diperoleh selama perkawinan menjadi harta bersama, dan Harta bawaan dari masing-masing suami dan istri dan harta benda yang diperoleh masing-masing sebagai hadiah atau warisan adalah di bawah penguasaan masing-masing sepanjang para pihak tidak menentukan lain.

Pada Pasal 36 Undang-Undang Perkawinan menyatakan bahwa mengenai harta bersama, suami dan istri dapat bertindak atas persetujuan kedua belah pihak, dan harta bawaan masing-masing suami dan istri mempunyai hak sepenuhnya untuk melakukan perbuatan hukum mengenai harta bendanya.

Pada Pasal 37 Undang-Undang Perkawinan menyatakan bahwa bila perkawinan putus karena perceraian harta bersama diatur menurut hukumnya masing-masing. Jika diperhatikan maka Pasal 37 Undang-Undang Perkawinan dan penjelasannya, tidak memberikan keseragaman hukum positif tentang bagaimana penyelesaian harta bersama apabila terjadi perceraian. Kalau dicermati pada penjelasan Pasal 37 Undang-Undang Perkawinan, maka undang-undang ini memberikan jalan pembagian sebagai berikut: Pertama, Dilakukan berdasarkan hukum agama jika hukum agama itu merupakan kesadaran hukum yang hidup dalam mengatur tata cara perceraian; Kedua, Aturan pembagiannya akan dilakukan menurut hukum adat, jika hukum tersebut merupakan kesadaran hukum yang hidup dalam lingkungan masyarakat yang bersangkutan; Ketiga, atau hukum-hukum lainnya. (M. Yahya Harahap, 1975:125)

Dari Pasal 35 Undang-Undang Perkawinan menyimpulkan bahwa harta dalam perkawinan berupa: 1. Harta Bersama, dan 2. Harta Pribadi dapat berupa: Harta bawaan suami, Harta bawaan istri, Harta hibahan/warisan suami, dan Harta hibahan/warisan istri (Satrio J., 1990:59). 
Berdasarkan pendapat ahli hukum lainnya, dalam suatu perkawinan terdapat tiga macam harta kekayaan, yaitu: Pertama, Harta pribadi suami ialah Harta bawaan suami, yaitu yang dibawa sejak sebelum perkawinan, dan Harta yang diperolehnya sebagai hadiah atau warisan. Kedua, Harta pribadi istri ialah: Harta bawaan istri, yaitu yang dibawanya sejak sebelum perkawinan, dan Harta yang diperolehnya sebagai hadiah atau warisan. Ketiga, Harta bersama suami istri ialah harta yang diperoleh baik sendiri-sendiri atau bersama suami-istri selama dalam ikatan perkawinan, tanpa mempersoalkan terdaftar atas nama siapapun (Arto Mukti, 1998:70). Jadi dengan demikian menurut pendapat di atas, harta yang telah dipunyai pada saat (dibawa masuk ke dalam) perkawinan terletak diluar harta bersama.

Sayuti Thalib, berpendapat bahwa harta bersama dibagi dalam 3 (tiga) kelompok yaitu:

Pertama, Dilihat dari sudut asal usul harta suami istri itu dapat digolongkan pada 3 golongan yaitu: 1 . Harta masing-masing suami atau istri yang didapat sebelum perkawinan adalah harta bawaan atau dapat dimiliki secara sendiri-sendiri; 2 . Harta yang diperoleh sepanjang perkawinan itu berjalan, tetapi bukan dari usaha mereka melainkan hibah, wasiat atau warisan adalah harta masing-masing; 3. Harta yang diperoleh sepanjang perkawinan, baik usaha sendiri suami atau istri maupun bersama-sama merupakan harta pencarian atau harta bersama.

Kedua, Dilihat dari sudut pandang pengguna, maka harta dipergunakan untuk: 1. Pembiayan untuk rumah tangga, keluarga dan belanja sekolah anakanak; 2. Harta kekayaan yang lain.

Ketiga, Dilihat dari sudut hubungan harta dengan perorangan dalam masyarakat, harta itu akan berupa: 1. Harta milik bersama; 2. Harta milik seseorang tapi terikat pada keluarga; 3 . Harta milik seseorang dan pemiliknya dengan tegas oleh yang bersangkutan (Sayuti Thalib, 1974:83).

Mengenai harta kekayaan yang didapat sepanjang perkawinan inilah yang akan dibagi jika perkawinan itu putus, baik karena perceraian, kematian ataupun putusan pengadilan. Penetapan harta bersama dalam perkawinan sangat penting sebagai penguasaan dan pembagiannya yakni penguasaan terhadap harta bersama dalam hal perkawinan masih berlangsung serta pembagian harta bersama dilakukan ketika terjadi putusnya perkawinan. Selain itu ketentuan harta bersama dalam Undang-Undang Perkawinan di atas tidak menyebutkan dari mana atau dari siapa harta itu berasal, sehingga boleh disimpulkan bahwa yang termasuk dalam harta bersama adalah: 1 . Hasil dan pendapatan suami selama masa perkawinan; 2 . Hasil dan pendapatan istri selama masa perkawinan; 3 . Hasil dan pendapatan dari harta pribadi suami maupun istri, sekalipun harta pokoknya tidak termasuk dalam harta bersama, asal semuanya diperoleh selama masa perkawinan (Satrio J., 1990:189).

Dalam Undang-Undang Perkawinan tidak diatur secara jelas pembagian harta bersama apabila perkawinan putus karena perceraian. Dalam Pasal 37 UndangUndang Nomor 1 Tahun 1974 tentang Perkawinan hanya disebutkan bahwa, bila perkawinan putus karena perceraian, harta bersama diatur menurut hukumnya masing-masing. Pengertian hukumnya masing-masing, menegaskan dapat meliputi hukum agama, hukum adat atau hukum-hukum lainnya yaitu hukum yang berlaku bagi perkawinan tersebut (Penjelasan Pasal 37 Undang-Undang Nomor 1 Tahun 1974 tentang Perkawinan). Berdasarkan uraian tersebut dapat diambil kesimpulan bahwa penjelasan ketentuan Pasal 37 Undang-Undang Nomor 1 Tahun 1974 menurut hukum masing-masing yaitu hukum agama, hukum adat dan hukum lainnya dapat menimbulkan perbedaan penafsiran mengenai harta bersama pasca perceraian dan dapat terjadi konflik atau pertentangan dalam keberlakuan salah satu hukum tersebut.

Berdasarkan pendapat M. Yahya Harahap, pikiran pembuat undang-undang mengenai penyelesaian pembagian harta bersama diserahkan kepada kehendak dan kesadaran masyarakat dan hakim yang akan mencari dan menemukan dalam kesadaran hukum masyarakat untuk dituangkan sebagai hukum objektif. Pendapat kedua ia menyatakan pembuat undang-undang tidak usah ditentukan one way traffic sebagai satu saluran hukum positif sebab berdasarkan kenyataan kesadaran hukum yang hidup dalam masyarakat, tentang hal ini masih menuju perkembangan bentuk yang lebih serasi sebagai akibat meluasnya interaksi antara segala unsur kesadaran yang sedang dialami oleh bangsa Indonesia (Satrio J., 1990:189).

Namun berdasarkan yurisprudensi pada keputusankeputusan pengadilan tentang pembagian harta bersama pasca perceraian, harta bersama yang diperoleh selama perkawinan harus dibagi dua bersama antara suami dan istri. Hal ini dapat dilihat dalam pertimbangan Pengadilan Tinggi Medan Nomor 389/1971 tanggal 30 Desember 1971 jo Mahkamah Agung Nomor 31 
R/Sip/1972 tanggal 25 Mei 1973 jo Putusan Pengadilan Negeri Medan Nomor 129/1972 tanggal 2 Juli 1973 jo Pengadilan Tinggi Medan Nomor 358/1973 tanggal 2 Juli 1973 jo Pengadilan Tinggi Tasikmalaya Nomor 44/1967 tanggal 27 Maret 1968 jo Pengadilan Tinggi Bandung Nomor 198/1969 tanggal 3 Desember 1970 jo Pengadilan Tinggi Tegal Nomor 27/1971 tanggal 16 Maret 1972 (Satrio J., 1990:127).

\section{Konsepsi Harta Bersama Berdasarkan Hukum Islam dan Kompilasi Hukum Islam}

Pada dasarnya Hukum Islam tidak mengenal istilah percampuran harta kekayaan antara suami atau istri karena pernikahan. Harta kekayaan istri tetap menjadi milik istri dan dikuasai penuh olehnya, demikian pula harta kekayaan suami menjadi milik suami dan dikuasai penuh oleh suami (Ismuha, 1978: 38). Jadi secara garis besar mengenai harta gono-gini atau harta bersama sebenarnya tidak dijumpai dalam kitab-kitab fiqh klasik. Pada saat itu, masalah harta harta bersama merupakan persoalan hukum yang belum disentuh atau belum terpikirkan (ghair almufakkar) oleh para ulama figh masa lalu karena masalah harta bersama baru muncul dan banyak dibicarakan dalam masa emansipasi wanita seperti yang terjadi masa ini.

Secara umum, hukum Islam tidak melihat adanya harta gono-gini. Hukum Islam lebih memandang adanya keterpisahan antara harta suami dan harta istri. Apa yang dihasilkan oleh suami merupakan harta miliknya, demikian juga sebaliknya, apa yang dihasilkan istri adalah harta miliknya. Menurut pendapat M. Yahya Harahap, bahwa perspektif hukum Islam tentang gono-gini atau harta bersama sejalan dengan apa yang dikemukakan oleh Muhammad Syah bahwa pencaharian bersama suami istri mestinya masuk dalam rub'u mu'amalah, tetapi ternyata tidak dibicarakan secara khusus. Hal mungkin disebabkan karena pada umumnya pengarang kitab-kitab fiqh adalah orang Arab yang tidak mengenal adanya pencaharian bersama suami istri. Tetapi ada dibicarakan tentang kongsi yang dalam bahasa Arab disebut syirkah. Oleh karena masalah pencaharian bersama suami istri adalah termasuk perkongsian atau syirkah (Abd. Rasyid As'ad, 2010:2).

Pendapat dari Zahri Hamid dalam buku PokokPokok Hukum Perkawinan Islam dan Undang-Undang Perkawinan di Indonesia menyatakan, hukum Islam mengatur sistem terpisahnya harta suami dan harta istri sepanjang yang bersangkutan tidak menentukan lain (tidak ditentukan dalam perjanjian perkawinan). Hukum Islam juga memberikan kelonggaran kepada mereka berdua untuk membuat perjanjian perkawinan sesuai dengan keinginan mereka berdua, dan perjanjian tersebut akhirnya mengikat mereka secara hukum. Senada dengan itu, Ahmad Azhar Basyir dalam bukunya Hukum Perkawinan Islam menyatakan, hukum Islam memberi hak kepada masing-masing pasangan, baik suami atau istri untuk memiliki harta benda secara perseorangan yang tidak bisa diganggu oleh masing-masing pihak. Suami yang menerima pemberian, warisan dan sebagainya, berhak menguasai sepenuhnya harta yang diterimanya itu, tanpa adanya campur tangan istrinya. Demikian halnya bagi istri yang menerima pemberian, warisan, dan sebagainya, berhak menguasai sepenuhnya harta yang diterimanya itu tanpa adanya campur tangan suaminya. Dengan demikian, harta bawaan yang mereka miliki sebelum terjadinya perkawinan menjadi hak milik masingmasing pasangan suami istri.

Pendapat kedua pakar tersebut, tentu yang dimaksud bukanlah harta gono-gini, tetapi harta bawaan atau harta perolehan masing-masing pasangan suami istri, namun demikian, ketentuan hukum Islam yang memisahkan harta kekayaan suami istri sebenarnya akan memudahkan bagi pasangan suami istri bila terjadi proses perceraian karena prosesnya menjadi tidak rumit dan berbelit-belit.

Hukum Islam juga berpendirian, bahwa harta yang diperoleh suami selama dalam perkawinan menjadi hak suami, sedangkan istri hanya berhak terhadap nafkah yang diberikan suami kepadanya. Namun, AlQur'an maupun Hadits tidak memberikan ketentuan yang tegas bahwa harta yang diperoleh suami selama dalam perkawinan sepenuhnya menjadi hak suami, dan istri hanya terbatas atas nafkah yang diberikan oleh suami. Ketidaktegasan dalam Al-Qur' an maupun Hadits tersebut, menurut Ahmad Azhar Basyir, istri secara langsung juga berhak terhadap harta tersebut. Berdasarkan hal tersebut, maka sesungguhnya masalah harta gono-gini atau harta bersama tidak disinggung secara jelas dan tegas dalam hukum Islam. Dengan kata lain, masalah harta gono-gini merupakan wilayah hukum yang belum terpikirkan (ghairu al mufakkar fih) dalam hukum Islam, sehingga oleh karena itu, terbuka bagi ahli hukum Islam untuk melakukan ijtihad dengan pendekatan qiyas (Abd. Rasyid As'ad, 2010:4) 
Ijtihad berfokus dalam segala kemampuan untuk menghasilkan hukum syara' yang bersifat praktikal melalui kaedah istinbat (rumusan tentang hukum) (Suhairimi bin Abdullah). Sedangkan pengertian qiyas secara garis besar pengertiannya adalah mempersamakan hukum suatu kasus yang tidak dinashkan dalam Al-Qur'an dengan hukum kasus lain yang dinashkan karena persamaan illat hukum. (Djazuli A. dan I Nurol Aen, 2000:121)

Dalam ajaran Islam, ijtihad itu diperbolehkan asalkan berkenaan dengan masalah-masalah yang belum ditemukan dasar hukumnya. Masalah harta gono-gini merupakan wilayah keduniaan yang belum tersentuh oleh hukum Islam klasik. Hukum Islam kontemporer tentang harga gono-gini dianalisis melalui pendekatan ijtihad, yaitu bahwa harta yang diperoleh pasangan suami istri selama dalam ikatan perkawinan merupakan harta gono-gini.

Kajian ulama tentang gono-gini telah melahirkan pendapat bahwa harta gono-gini termasuk dapat diqiyaskan sebagai syirkah. KH. Ma'ruf Amin, Ketua Komisi Fatwa MUI Pusat mengatakan, harta gono-gini dapat disamakan atau digolongkan ke dalam harta syirkah, yaitu harta yang terkumpul selama menikah harus dibagi secara proporsional jika terjadi perceraian. Harta gono-gini dapat diqiyaskan dengan syirkah karena dipahami istri juga dapat dihitung sebagai pasangan atau kongsi yang bekerja, meskipun tidak ikut bekerja dalam pengertian yang sesungguhnya. Maksudnya, istri yang bekerja dalam pengertian mengurus rumah tangga, seperti memasak, mencuci pakaian, mengasuh anak, membereskan rumah tangga, dan pekerjaan domestik lainnya, juga dianggap sebagai aktifitas kerja yang perannya tidak bisa dipandang sebelah mata (Happy Susanto, 2008:59).

Harta gono-gini yang didefinisikan sebagai harta yang dihasilkan oleh pasangan suami istri selama perkawinan berlangsung, maka harta gonogini dapat kategorikan sebagai syirkah mufawadhah atau juga syirkah abdan. Syirkah mufawadhah adalah suatu bentuk perkongsian dua belah pihak yang melakukan kegiatan usaha, sedangkan pihak ketiga sebagai pemodal. Sedangkan syirkah abdan adalah suatu bentuk perkongsian dua pihak atau lebih yang masing-masing anggotanya hanya melakukan kegiatan usaha, namun tidak memberikan modal (Abd. Rasyid As'ad, 2010:5).

Jika harta gono-gini diqiyaskan dengan syirkah sangatlah masuk akal karena sama-sama mengandung pengertian sebagai suatu bentuk perkongsian atau kerjasama antara suami dan istri. Hanya saja dalam konsep syirkah pada umumnya lebih bersifat bisnis atau kerja sama dalam kegiatan usaha, sedangkan syirkah gono-gini sifatnya hanya kerjasama dalam membangun sebuah rumah tangga yang sakinah, mawaddah, warahmah, meskipun juga meliputi halhal yang berkaitan dengan harta dalam perkawinan. Pengqiyasan antara gono-gini dengan syirkah dapat pula dipahami melalui argumentasi sebagai berikut. Bahwa persatuan atau percampuran harta kekayaan suami dan istri dapat dipahami sebagai harta kekayaan tambahan karena adanya usaha bersama antara mereka berdua. Logikanya, jika terjadi pemutusan hubungan (perceraian) di antara mereka, maka persatuan harta kekayaan (gono-gini) itu harus dibagi dua. Pembagiannya bisa ditentukan atas dasar mana pihak yang lebih banyak berinvestasi dalam kerja sama itu, apakah suami atau istri. Atau juga dapat dibagi secara merata, yaitu masing-masing pihak mendapatkan separuh.

Berbicara mengenai hukum Islam khususnya mengenai harta bersama maka secara yuridis formal tidak bisa dilepaskan keterkaitannya mengenai Kompilasi Hukum Islam yang merupakan hasil ijtihad yang mengandung peraturan-peraturan hukum Islam yang sesuai dengan kondisi kebutuhan hukum dan kesadaran hukum umat Islam di Indonesia. Tetapi kompilasi hukum Islam bukan mazhab baru dalam figh Islam, melainkan merupakan wujud dan penerapan berbagai mazhab figh yang ada serta dilengkapi dengan institusi lain seperti fatwa ulama sebagai respon terhadap masalah yang muncul, keputusan pengadilan lewat persidangan suatu perkara oleh para hakim, dan undang-undang yang dibuat oleh badan legislatif, untuk menjawab persoalan-persoalan yang ada di Indonesia sesuai dengan kesadaran hukum masyarakat Islam Indonesia itu sendiri (Andi Herawati, 2011:337).

Berdasarkan Kompilasi Hukum Islam, harta kekayaan dalam perkawinan diatur dalam Pasal 85 sampai dengan Pasal 97 pada Buku I (satu). Rumusan Pasal 85 sampai 97 Kompilasi Hukum Islam telah disetujui oleh para ahli hukum Islam di Indonesia untuk mengambil syirkah abdan sebagai landasan perumusan kaidah-kaidah harta gono-gini atau harta bersama (Abdul Manan, 2006:111). Para perumus Kompilasi Hukum Islam melakukan pendekatan dari jalur syirkah abdan dengan hukum adat. Cara pendekatan ini tidak bertentangan dengan kebolehan 
menjadikan 'urf(adat/tradisi) sebagai sumber hukum dan sejalan dengan kaidah yang mengatakan " $a l$ adatu muhakkamah" (Abd. Rasyid As'ad, 2010:6). Sebagian ahli hukum Islam memandang bahwa gonogini merupakan kehendak dan aspirasi hukum Islam. Menurut mereka, gono-gini adalah konsekuensi dari adanya hubungan perkawinan antara seorang laki-laki dan seorang wanita yang kemudian menghasilkan harta dari usaha yang mereka lakukan berdua selama ikatan perkawinan. Mereka mendasarkan pada firman Allah di dalam Al-Qur'an Surat An-Nisa: 21 yang menyebut perkawinan sebagai suatu perjanjian yang suci, kuat, dan kokoh (mitsaqan ghalizhan). Artinya, perkawinan yang dilakukan melalui ijab qabul dan telah memenuhi syarat dan rukunnya merupakan syirkah antara suami dan istri. Oleh karena itu, akibat hukum yang muncul kemudian, termasuk harta benda menjadi milik bersama.

Kompilasi Hukum Islam di Indonesia merupakan pengembangan dari hukum perkawinan yang tertuang di dalam Undang-Undang Perkawinan Nomor 1 Tahun 1974. Karena itu, ia tidak dapat lepas dari misi yang diemban oleh Undang-Undang Perkawinan tersebut kendatipun cakupannya hanya terbatas bagi kepentingan umat Islam. Antara lain, kompilasi mutlak harus mampu memberikan landasan hukum perkawinan yang dipegangi oleh umat Islam (Ahmad Rafiq, 1995: 269). Kompilasi Hukum Islam Pasal 91 menyatakan bahwa wujud harta bersama itu antara lain: pertama, 1 . Harta bersama sebagai tersebut dalam Pasal 85 dapat berupa benda berwujud atau tidak berwujud; kedua, Harta bersama yang berwujud dapat meliputi benda bergerak, tidak bergerak dan surat-surat berharga lainnya; ketiga, Harta bersama yang tidak berwujud dapat berupa hak maupun kewajiban; keempat, Harta bersama dapat dijadikan sebagai barang jaminan oleh salah satu pihak atas persetujuan pihak lain (M. Fauzan Abdul Manan, 2001:75). Sementara Pasal 92 Kompilasi Hukum Islam berbunyi, suami atau istri tanpa persetujuan para pihak lain tidak diperbolehkan menjual atau memindahkan harta bersama.

Jadi terhadap harta bersama ini, pihak suami atau istri mempunyai tanggung jawab yang sama dan harta bersama itu akan dibagi sama atau fiftyfifty apabila perkawinan tersebut sudah putus akibat kematian atau pun perceraian dan karena putusan pengadilan. Berdasarkan analisa, pasal-pasal yang mengatur tentang harta bersama adalah Pasal 88 dan 95. Pasal 88 mengatur bahwa bila terdapat sengketa atas harta bersama, maka akan diserahkan kepada Pengadilan Agama yang berwenang. Pasal tersebut merupakan pasal dalam Kompilasi Hukum Islam yang mengatur tentang pembagian harta bersama bila terjadi perselisihan. Kompilasi Hukum Islam menyerahkan semua hal yang berkaitan dengan pembagian harta bersama kepada Pengadilan Agama yang berwenang menyelesaikan permohonan sengketa harta bersama tersebut. Diserahkan kepada Pengadilan Agama berarti penentuan dari perkara yang dihadapi berada di tangan majelis hakim yang memutus perkara berdasarkan bukti-bukti yang ada dalam persidangan dan juga saksi yang diajukan masing-masing pihak. Penyelesaian melalui pengadilan ini merupakan sebuah alternatif penyelesaian perkara. Pasangan dapat memilih cara yang lebih elegan yaitu dengan cara damai atau musyawarah. Cara ini jauh lebih baik karena tidak perlu berbelit-belit, memakan waktu, memakan biaya, dan atau juga memakan perasaan para pihak. Cara ini dapat dipergunakan selama dilakukan dengan seadiladilnya. Dalam musyawarah para pihak dapat sepakat mengenai presentase pembagian harta bersama, tidak harus setengah-setengah. Istri dapat memperoleh presentase sepertiga dan suami dua pertiga atau sebaliknya asalkan tidak ada yang merasa dirugikan atau dicurangi. Namun jika memang cara penyelesaian sengketa melalui jalur damai tidak dapat terlaksana dan jalur hukum (pengadilan) dianggap lebih tepat dalam hal memperoleh keadilan, maka hal tersebut dapat dilakukan.

\section{Konsepsi menurut Kitab Undang-Undang Hukum Perdata}

Berdasarkan ketentuan Pasal 124 KUHPerdata, suamilah yang berhak mengurus harta bersama, termasuk berwenang melakukan berbagai perbuatan terhadap harta tersebut. Isi Pasal 124 KUHPerdata tersebut antara lain adalah: pertama, Hanya suami saja yang boleh mengurus harta bersama itu; kedua, Dia boleh menjualnya, memindahtangankan dan membebaninya tanpa bantuan istrinya, kecuali dalam hal yang diatur dalam Pasal 140; ketiga, Dia tidak boleh memberikan harta bersama sebagai hibah antara mereka yang samasama masih hidup, baik barang-barang tak bergerak maupun keseluruhannya atau suatu bagian atau jumlah yang tertentu dan barang-barang bergerak, bila bukan kepada anak-anak yang lahir dan perkawinan mereka, untuk memberi suatu kedudukan; keempat, Bahkan dia tidak boleh menetapkan ketentuan dengan cara 
hibah mengenai sesuatu barang yang khusus, bila dia memperuntukkan untuk dirinya hak pakai hasil dari barang itu.

Berdasarkan ketentuan tersebut dapat diketahui bahwa si suami sendiri yang mengurus persatuan harta kekayaan, hanya si suami yang berwenang melakukan perbuatan-perbuatan terhadap harta kekayaan tersebut, dan si istri tidak boleh ikut campur dalam pengurusan tersebut. Namun demikian ada perkecualian, yakni suami tidak diperbolehkan mengurus sebagaimana dinyatakan dalam Pasal 140 ayat 3 yang menyatakan, mereka juga berhak untuk membuat perjanjian, bahwa meskipun ada golongan harta bersama, barang-barang tetap, surat-surat pendaftaran dalam buku besar pinjamanpinjaman negara, surat-surat berharga lainnya dan piutang-piutang yang diperoleh atas nama istri, atau yang selama perkawinan dan pihak istri jatuh ke dalam harta bersama, tidak boleh dipindahtangankan atau dibebani oleh suaminya tanpa persetujuan si istri.

Dalam Pasal 140 ayat 2 ditentukan bahwa, Demikian pula perjanjian itu tidak boleh mengurangi hak-hak yang diperuntukkan bagi si suami sebagai kepala persatuan suami istri, namun hal ini tidak mengurangi wewenang istri untuk mensyaratkan bagi dirinya pengurusan harta kekayaan pribadi, baik barang-barang bergerak maupun barang-barang tak bergerak, disamping penikmatan penghasilannya pribadi secara bebas. Perbuatan-perbuatan sebagaimana disebutkan dalam ayat 2 tersebut sifatnya memutus, bukan dalam pengertian mengurus (seperti dalam ayat 1). Maksudnya, perbuatan suami dibatasi, yaitu bahwa dia tidak berhak mengurusi harta-harta kekayaan di luar harta bersama, seperti harta bawaan dan harta perolehan karena kedua macam harta tersebut tetap menjadi wewenang masing-masing pasangan. Sebagai contoh, harta bawaan berupa hibah hanya dapat diurus apabila berkenaan dengan urusan kehidupan anakanak mereka.

Pada dasarnya, kebersamaan harta kekayaan dalam perkawinan tidak hanya berupa benda-benda bergerak dan tidak bergerak yang diperoleh selama masa perkawinan, baik dengan atas nama atau tidak atas nama istri/suami, tetapi juga berkaitan dengan yang dibawa oleh mereka berdua dalam perkawinan. Misalnya, benda-benda atas nama istri berupa tagihantagihan dan saham-saham yang dibawa olehnya selama perkawinan, maka benda-benda tersebut tidak dapat dibalik nama menjadi atas nama suami atau atas nama suami istri. Meskipun demikian, benda-benda tersebut tetap menjadi bagian dari harta bersama. Benda-benda tersebut boleh dijual, dipindahtangankan, atau dibebani oleh suami tanpa perantaraan istri.

Di samping adanya benda-benda yang merupakan bagian dari harta bersama, juga ada benda-benda yang tidak termasuk didalamnya, seperti harta hibah dan harta warisan. Kedua macam harta itu pada dasarnya merupakan harta bawaan atau harta perolehan yang tidak masuk dalam kategori harta bersama. Hal itu tidak berlaku, kecuali jika calon pasangan suami istri menentukan dalam perjanjian perkawinan yang mereka buat bahwa dua macam harta merupakan harta bersama (harta gono-gini). Hal ini ditentukan dalam KUHPerdata Pasal 120 yang menyatakan, berkenaan dengan soal keuntungan, maka harta bersama itu meliputi barang-barang bergerak dan barang-barang tak bergerak suami istri itu, baik yang sudah ada maupun yang akan ada, juga barang-barang yang mereka peroleh secara cuma-cuma, kecuali bila dalam hal terakhir ini yang mewariskan atau yang menghibahkan menentukan kebalikannya dengan tegas.

Berdasarkan penjelasan panjang lebar di atas, dapat ditegaskan kembali bahwa wewenang atau kekuasaan suami begitu besar terhadap pengurusan harta bersama. Suami tidak bertanggungjawab terhadap istri berkenaan dengan pengurusan tersebut. Dia juga tidak diwajibkan oleh istri untuk memberikan perhitungan kepadanya, termasuk jika nantinya kebersamaan harta bersama itu bubar. Meskipun demikian, kekuasaan suami yang begitu besar itu ternyata dibatasi oleh dua hal sebagai berikut: (Felicitas Marcelina Waha, 2013:58)

Pertama, Dibatasi oleh peraturan perundangundangan. Kekuasaan suami dalam mengurus harta bersama dibatasi oleh undang-undang. Hal ini diatur dalam KUHPerdata Pasal 124 ayat 3. Suami dan istri juga boleh menghibahkan secara bersama-sama. Pasal 124 ayat 3 di atas memberikan pengecualian terhadap hibah yang difungsikan untuk memerhatikan kedudukan anak-anak yang dilahirkan dari perkawinan mereka. Artinya, hibah yang dilakukan adalah untuk kepentingan anak-anak dan masa depannya. Dalam bentuk hibah seperti ini, suami diperbolehkan untuk tidak meminta bantuan istrinya.

Pasal 124 ayat 3 KUHPerdata melarang suami untuk menghibahkan sebagian dari harta bersarna tanpa persetujuan istrinya, kecuali untuk memberikan suatu kedudukan kepada anak-anak yang lahir dari perkawinan mereka. Hal ini diperkuat dengan yurisprudensi Putusan MA No. 871 K/Sip/1973. 
Suami memiliki batasan berkenaan dengan hibah terhadap benda-benda yang bergerak. Suami tidak diperbolehkan menghibahkan benda bergerak tertentu, kecuali diperjanjikan bahwa hak pakai hasilnya memang dihadiahkan kepada suami.

Kedua, Dibatasi dengan Kesepakatan Suami Istri dalam Perjanjian Perkawinan. Menurut ketentuan Pasal 119 KUHPerdata, apabila calon suami istri sebelum perkawinan dilangsungkan tidak dibuat perjanjian kawin, dalam mana persatuan (campuran) harta kekayaan dibatasi atau ditiadakan sama sekali, maka demi hukum akan ada persatuan (campuran) bulat antara harta kekayaan suami dan istri, baik yang mereka bawa dalam perkawinan, maupun yang mereka akan peroleh sepanjang perkawinan.

Sebelum perkawinan dilangsungkan, calon suami dan istri dengan membuat perjanjian kawin, dapat mengadakan penyimpangan dari peraturanperaturan yang ditentukan untuk persatuan harta kekayaan bulat tersebut. Persatuan harta kekayaan itu dapat dibatasi atau ditiadakan. Apabila dibatasi, maka akan ada persatuan harta kekayaan terbatas (beperkte gemeenschap dan goederen). Di dalam batas batas undang-undang, calon suami dan istri bebas menentukan sendiri pembatasan harta benda itu, sehingga ada berjenis-jenis persatuan harta kekayaan terbatas dan untuk dapat mengetahui persis keadaan persatuan harta kekayaan terbatas tertentu, maka harus suami istri harus memeriksa isi perjanjian kawin dengan seksama (Ko Tjay Sing, 1979:183).

Dalam perjanjian perkawinan dapat pula ditentukan bahwa suami tanpa bantuan istri tidak dapat memindahtangankah atau membebani bendabenda bergerak, dan surat-surat pendaftaran dalam buku besar perutangan umum, surat-surat berharga lain, piutang-piutang atas nama (benda-benda bergerak atas nama). Yang dimaksud benda-benda bergerak atas nama, misalnya atas nama istri dan dibawa masuk dalam perkawinan, atau barang-barang yang diperoleh sang istri sepanjang perkawinan. Dengan demikian, untuk dapat memindahtangankan atau membebani barang-barang tersebut harus ada kerjasama dan kesepakatan di antara mereka berdua (suami istri).

Perlu dicatat disini bahwa pada dasarnya akta perjanjian tidak banyak membantu istri karena suami memiliki hak yang sangat besar, yaitu bisa berutang tanpa izin istri. Wewenang suami yang sangat besar dikarenakan harta-harta yang termasuk dalam kebersamaan harta bersama, maka suami berhak melakukan pengurusan terhadapnya. Dengan demikian, meskipun pada akhirnya harta-harta istri itu atas nama dirinya sendiri, bisa disita dan dilelang untuk melunasi utang-utang yang tergolong dalam kebersamaan harta bersama.

Berdasarkan bahasan di atas, diketahui bahwa suami mempunyai kekuasaan yang begitu besar atas harta bersama, baik dalam pengurusan (beheren) maupun dalam perbuatan-perbuatan yang sifatnya memutus (beschikken) tanpa bantuan dan bahkan tanpa sepengetahuan istri. Meskipun demikian, istri mempunyai sejumlah hak yang didasarkan pada kondisikondisi tertentu. Istri diperbolehkan membebani atau memindahtangankan barang-barang persatuan dengan kondisi sebagaimana ditentukan dalam KUHPerdata Pasal 125.

Berdasarkan KUHPerdata, istri juga mempunyai hak untuk melepaskan bagiannya dalam kebersamaan harta kekayaan perkawinan, sebagai berikut: pertama, Istri tidak berhak lagi atas bagiannya dari aktiva harta bersama, kecuali hak atas pakaian, selimut, dan sprei. (KUHPerdata Pasal 132 ayat 1); kedua, Istri dibatasi kewajibannya dalam hal membayar utang-utang harta bersama (KUHPerdata Pasal 132 ayat 2).

Untuk batas waktu hak pelepasan yang ditentukan adalah sebulan setelah terjadinya pembubaran atas kebersamaan harta bersama. Dalam waktu sebulan ini, istri dapat mengajukan hak pelepasan kepada Panitera Pengadilan Negeri di tempat kediaman suami istri yang terakhir. Ketentuan ini diatur dalam KUHPerdata Pasal 133 ayat 1 . Jika pelepasan itu terjadi karena meninggalnya suami, batas waktu sebulan itu terhitung sejak meninggalnya suami yang memang diketahui oleh istrinya. Hal ini diatur dalam KUHPerdata Pasal 133 ayat 2 . Pasal 134 ayat 1 mengatur bahwa apabila istri meninggal dalam tenggang waktu sebulan sebelum menyampaikan akta pelepasan, "Maka para ahli warisnya berhak melepaskan hak mereka atas persatuan dengan cara seperti tersebut dalam pasal terakhir, dan dalam tenggang waktu selama satu bulan pula, setelah meninggalnya istri, atau setelah kematian itu oleh mereka diketahui". Lebih lanjut, ayat 2 pasal yang sama mengatur bahwa hak istri untuk barang-barang selimut dan seprei, tidak bisa diperjuangkan oleh para ahli warisnya. Hilangnya hak pelepasan ini diatur dalam KUHPerdata Pasal 136 dan Pasal 137.

Mengenai pembagian harta bersama dalam perkawinan setelah perceraian, pada umumnya harta 
bersama dibagi dua sama rata di antara suami dan istri. Hal ini didasarkan pada ketentuan Pasal 128 KUHPerdata. Pembagian harta bersama bagusnya dilakukan secara adil, sehingga tidak menimbulkan ketidakadilan antara mana yang merupakan hak suami dan mana hak istri. Apabila terjadi perselisihan antara suami istri tentang harta bersama, maka penyelesaian perselisihan itu diajukan kepada pengadilan. Penyelesaian melalui jalur pengadilan adalah sebuah pilihan. Ketentuan tentang pembagian harta bersama didasarkan pada kondisi yang menyertai hubungan suatu perkawinan, seperti kematian, perceraian, dan sebagainya.

\section{Konsepsi Berdasarkan Hukum Adat}

Hukum Perkawinan Adat adalah keseluruhan kaidah hukum yang menentukan prosedur yang harus ditempuh oleh dua orang yang bertalian kelamin dalam menciptakan kehidupan bersama dalam suatu rumah tangga dengan tujuan untuk meneruskan keturunan (Djaren Saragih, 1992:1). Hilman Hadikusuma, menyebutkan Hukum Adat Perkawinan adalah aturan-aturan hukum adat yang mengatur tentang bentuk-bentuk perkawinan, cara-cara pelamaran, upacara perkawinan dan putusnya perkawinan di Indonesia (Hilman Hadikusuma, 1992:182).

Mengenai peristiwa perceraian menurut hukum adat adalah merupakan peristiwa yang luar biasa, merupakan problem sosial dan yuridis yang penting dalam kebanyakan daerah di Indonesia. Menurut Djojodigoeno sebagaimana dikutip oleh Tolib Setiady (2008:267) menyatakan, Perceraian ini di kalangan orang-orang Jawa adalah suatu hal yang tidak disukai karena cita-cita orang Jawa berjodohan seumur hidup sampai Kakek-Ninen. Hal ini pada umumnya telah menjadi pandangan seluruh bangsa yang sedapatdapatnya perceraian itu wajib dihindari.

Menurut hukum adat yang dimaksud harta perkawinan adalah, semua harta yang dikuasai suami istri selama mereka terikat dalam ikatan perkawinan, baik harta kerabat yang dikuasai, maupun harta perorangan yang berasal dari harta warisan, harta hibah, harta penghasilan sendiri, harta pencaharian hasil bersama suami istri, dan barang-barang hadiah. Kesemuanya itu dipengaruhi oleh prinsip kekerabatan yang dianut setempat dan bentuk perkawinan yang berlaku terhadap suami istri yang bersangkutan (Hilman Hadikusuma, 1992:156).

Sedangkan Harta Perkawinan dalam hukum adat, menurut Ter Haar, dapat dipisah menjadi empat macam sebagai berikut: pertama, Harta yang diperoleh suami atau istri sebagai warisan atau hibah dari kerabat masing-masing dan dibawa ke dalam perkawinan; kedua, Harta yang diperoleh suami atau istri untuk diri sendiri serta atas jasa diri sendiri sebelum perkawinan atau dalam masa perkawinan; ketiga, Harta yang dalam masa perkawinan diperoleh suami dan istri sebagai milik bersama; keempat, Harta yang dihadiahkan kepada suami dan istri bersama pada waktu pernikahan (Muhamad Isna Wahyudi, 2008:4).

Penyebutan harta bersama suami-istri berbeda dari satu daerah dengan daerah lainnya. Di Minangkabau harta bersama disebut dengan harta suarang, di Kalimantan disebut barang perpantangan, di Bugis disebut dengan cakkara, di Bali disebut dengan druwe gabro, di Jawa disebut dengan barang gini atau gonogini, dan di Pasundan disebut dengan guna kaya, barang sekaya, campur kaya, atau kaya reujeung. Di beberapa daerah terdapat pengecualian terhadap harta bersama tersebut. Di Aceh, penghasilan suami menjadi milik pribadinya sendiri, apabila istrinya tidak memberikan suatu dasar materiil (misal yang berbentuk suatu kebun atau suatu pekarangan kediaman) bagi keluarga atau tidak memberi bekal kepada suaminya yang mengadakan suatu perjalanan. Sementara di Jawa Barat, apabila pada saat perkawinan istri kaya sedangkan suami miskin (perkawinan nyalindung kagelung), maka penghasilan yang diperoleh semasa perkawinannya menjadi milik istri sendiri. Di Kudus Kulon (Jawa Tengah) dalam lingkungan para pedagang, maka suami dan istri masing-masing tetap memiliki barang-barang yang mereka bawa ke dalam perkawinan dan juga barang-barang yang mereka peroleh masing-masing selama selama perkawinan. Adanya harta bersama dalam perkawinan merupakan gejala umum dan telah menjadi azas umum dalam hukum adat seiring dengan pertumbuhan somah (suami dan istri sebagai suatu kesatuan bersama anak-anaknya dalam masyarakat adat) yang semakin kuat di dalam masyarakat yang menggeser kedudukan dan pengaruh keluarga besar atau kerabat dalam masalah harta perkawinan.

Konsepsi di beberapa daerah mengenai harta bersama adalah, segala kekayaan yang diperoleh suami atau istri selama perkawinan berlangsung termasuk harta bersama, selama suami istri tersebut sama-sama bekerja untuk keperluan somah. Lingkup pengertian bekerja itu pada akhirnya semakin luas dan kabur, sehingga seorang istri yang bekerja 
di rumah saja untuk memelihara anak-anak dan mengurus rumah tangga, sudah dianggap bekerja juga, sehingga dalam hal ini semua kekayaan yang secara konkrit diperoleh suami menjadi harta bersama. Ini adalah sesuatu yang wajar, sebab meskipun pihak istri tidak bekerja sendiri untuk memperoleh harta tersebut, namun dengan memelihara anak-anak dan membereskan urusan rumah tangga itu, pihak suami telah menerima bantuan yang sangat berharga dan sangat mempengaruhi kelancaran pekerjaannya sehari-hari, sehingga secara tidak langsung juga mempengaruhi jumlah harta yang diperoleh. Selain itu, apabila dalam mengurus rumah tangga sehari-hari, istri mampu melakukan penghematan yang pantas, maka secara langsung istri juga membantu dalam memelihara dan memperbesar harta milik bersama suami istri. Oleh karena itu, anggapan umum yang saat ini berlaku adalah bahwa harta yang diperoleh selama dalam perkawinan selalu menjadi milik bersama suami istri, tanpa mempersoalkan siapakah yang sesungguhnya berjerih payah memperoleh harta tersebut. Hukum adat juga mengatur pembagian harta bersama ketika perkawinan berakhir akibat kematian salah satu pihak atau akibat perceraian. Tidak ada keseragaman dalam hukum adat mengenai tata cara pembagian harta bersama. Namun demikian yang menjadi arus utama dalam pembagian harta bersama adalah bahwa suami atau istri masing-masing mendapat separuh dari harta bersama.

Mengenai pembagian harta bersama, beberapa daerah di Jawa Tengah memiliki kebiasaan yaitu suami mendapatkan duapertiga dan istri mendapat sepertiga. Azas pembagian tersebut di Jawa Tengah disebut azas sakgendong sakpikul. Tata cara pembagian seperti ini juga dikenal di pulau Bali berdasarkan azas sasuhunsarembat. Demikian pula di Kepulauan Banggai, terdapat azas dua-pertiga dan sepertiga tersebut. Akan tetapi, dalam perkembangannya, azas sakgendong sakpikul, atau sasuhun-sarembat, dalam pembagian harta bersama makin lama makin lenyap. Jika salah satu pihak meninggal dunia, maka lazimnya semua harta bersama tetap berada di bawah kekuasaan pihak yang masih hidup dan dia berhak untuk menggunakan harta bersama tersebut untuk keperluan hidupnya. Tetapi, dalam hal sudah tersedia secara pantas sejumlah harta yang diambilkan dari harta bersama tersebut untuk keperluan hidupnya, maka kelebihannya dapat dibagi oleh para ahli waris. Kalau terdapat anak, maka anak itulah yang menerima bagiannya sebagai barang asal. Sedangkan kalau tidak ada anak, maka sesudah kematian suami atau istri yang hidup lebih lama, harta bersama tersebut harus dibagi antara kerabat suami dan kerabat istri menurut ukuran pembagian yang sama dengan ukuran pembagian yang digunakan suami istri seandainya mereka masih hidup serta membagi harta bersama tersebut.

\section{PENUTUPAN \\ Kesimpulan}

Menurut Pasal 37 Undang-Undang Perkawinan Nomor 1 Tahun 1974 dinyatakan bahwa apabila perkawinan putus karena perceraian maka harta bersama diatur menurut hukumnya masing-masing. Harta yang diperoleh selama berlangsungnya perkawinan merupakan harta bersama. Sedangkan dalam Kompilasi Hukum Islam dan Kitab Undang-Undang Hukum Perdata, harta bersama setelah terjadinya perceraian akan dibagi dua yakni setengah untuk suami dan setengah untuk istri. Mengenai pembagian harta bersama secara Adat, beberapa daerah di Jawa Tengah memiliki kebiasaan yaitu suami mendapatkan duapertiga dan istri mendapat sepertiga. Azas pembagian tersebut di Jawa Tengah disebut azas sakgendong sakpikul. Tata cara pembagian seperti ini juga dikenal di Pulau Bali berdasarkan azas sasuhun-sarembat. Demikian pula di Kepulauan Banggai, terdapat azas duapertiga dan sepertiga tersebut.

\section{Rekomendasi}

Dalam perkawinan, suatu hal yang kerapkali menimbulkan permasalahan adalah harta bersama. Permasalahan ini kerapkali muncul bilamana dalam perkawinan tersebut berujung pada perceraian dan sudah barang tentu para pihaknya akan mempermasalahkan harta gono-gini dari harta bersama tersebut. Berdasarkan pembahasan, diketahui bahwa sebenarnya baik dalam Kompilasi Hukum Islam, KUHPerdata, Undang-Undang Perkawinan atau pun Hukum Adat dikenal adanya harta bersama, namun yang kerapkali dipermasalahkan adalah jumlah pembagian yang dinilai adil bagi para pihak. UUP yang secara tegas tidak memberlakukan aturan perkawinan dalam KUHPerdata menegaskan bahwa jumlah pembagian diserahkan menurut hukumnya masing-masing (hukum perkawinannya), maka disini UUP menyerahkan pembagian berdasarkan KHI. KHI menemukan aturan harta bersama melalui pendekatan jalur syirkah abdan dengan hukum adat yang, yang mana juga memberikan kesempatan pada para pihak 
untuk menentukan sendiri besar-kecilnya pembagian. Dalam hukum adat diatur jumlah yang berbeda-beda di setiap daerah yang diharapkan dapat menciptakan keadilan. Maka dari itu seyogyanya pembagian harta gono-gini dilakukan berdasarkan hukum adat yang mana hukum adat merupakan dasar pertimbangan dari pembentukan aturan-aturan perkawinan yang ada pada saat ini.

Karena bagaimanapun aturan hukum adat sudah barang tentu berbeda satu sama lain, maka tidak akan bisa tercipta. Unifikasi aturan pembagian harta gonogini, namun dapat ditentukan unifikasi konsep harta gono-gini dan aturan hukum adat yang sebaiknya diterapkan.

\section{DAFTAR PUSTAKA}

\section{Buku:}

As'ad, Abd. Rasyid. Gono-Gini dalam Perspektif Hukum Islam. Jurnal Pengadilan Agama. Oktober 2010.

Departemen Pendidikan dan Kebudayaan (Pusat Bahasa). 2001. Kamus Besar Bahasa Indonesia (Edisi ke-3). Jakarta: Balai Pustaka.

Djazuli, A. dan I Nurol Aen. 2000. Ushul Fiqh, Metodologi Hukum Islam. Jakarta: Raja Grafindo Persada.

Hadikusuma, Hilman. 1992. Pengantar Ilmu Hukum Adat Indonesia. Bandung: Mandar Maju.

Harahap, M. Yahya. 1975. Pembahasan Hukum Perkawinan Nasional Berdasarkan UndangUndang Nomor 1 Tahun 1974, Peraturan Pemerintah Nomor 9 Tahun 1974. Cet. I. Medan: Zahir Trading Co.

Herawati, Andi. Kompilasi Hukum Islam (KHI) sebagai Hasil Ijtihad Ulama Indonesia, Vol. 8 No. 2 Desember 2011:321-340, Hunafa: Jurnal Studia Islamika. Makassar. 2011.

Ismuha. 1978. Pencaharian Bersama Suami Istri di Indonesia. cet. 2. Jakarta: Bulan Bintang.
Manan, Abdul dan M. Fauzan. 2001. Pokok-pokok Hukum Perdata Wewenang Peradilan Agama. Jakarta: Raja Grafindo Persada. . 2006. Aneka Masalah Hukum Perdata Islam di Indonesia. Jakarta: Kencana.

Mukti, Arto. 1998. Praktek Perkara Perdata pada Pengadilan Agama. Yogyakarta: Pustaka Pelajar.

Rafiq, Ahmad. 1995. Hukum Islam di Indonesia. Jakarta: Raja Grafindo Persada.

Saragih, Djaren. 1992. Hukum Perkawinan Adat dan Undang-Undang tentang Perkawinan serta Peraturan Pelaksananya. Bandung: Tarsito.

Satrio, J. 1990. Hukum Harta Perkawinan. Bandung: Cipta Aditya Bakti.

Setiady, Tolib. 2008. Intisari Hukum Adat Indonesia dalam Kajian Kepustakaan. Bandung: Alfabeta.

Sing, Ko Tjay. 1979. Hukum Perdata Jilid I Hukum Keluarga. Bandung: Citra Aditya Bakti.

Suhairimi bin Abdullah. Konsep Ijtihad Menurut Perundangan Islam. Pusat Kemahiran Komunikasi dan Keusahawanan. Malaysia. tanpa tahun.

Susanto, Happy. 2008. Pembagian Harta Gono-Gini saat Terjadinya Perceraian, Pentingnya Perjanjian Perkawinan untuk Mengantisipasi Masalah Harta Gono-Gini. Jakarta: Visimedia.

Thalib, Sayuti. 1974. Hukum Kekeluargaan Indonesia. Jakarta: Yayasan Penerbit UI.

Waha, Felicitas Marcelina. 2013. Penyelesaian Sengketa atas Harta Perkawinan setelah Bercerai. Lex et Societatis. Vol.I/No.1/Jan-Mrt/2013. Manado.

Wahyudi, Muhamad Isna. Harta Bersama: antara Konsepsi dan Tuntutan Keadilan, Jurnal MARI. Edisi Agustus 2008.

\section{Peraturan Perundang-undangan:}

Undang-Undang Nomor 1 Tahun 1974 tentang Perkawinan.

Kitab Undang-Undang Hukum Perdata.

Kompilasi Hukum Islam. 